\title{
Co po Unii? \\ Polska a procesy (dez)integracyjne w Europie
}

\section{Wprowadzenie}

Artykuł ten koncentruje się na refleksji wokół problematyki polskiej polityki w obliczu symptomów szeroko pojętego kryzysu zjawisk integracyjnych w Europie. Dające się aktualnie zaobserwować rozmaite perturbacje w Unii Europejskiej mogą skłaniać do poszukiwania odpowiedzi na pytania o kierunki działania polskiego rządu w przypadku ewentualnego pogłębiania się tendencji dezintegracyjnych unijnej wspólnoty, które niestety nie wydają się już tak mało prawdopodobne. Warto zastanowić się, czy polskie władze powinny dysponować choćby zarysem scenariusza postępowania na wypadek gwałtownego rozpadu tej organizacji bądź jej stopniowej marginalizacji jako aktora polityki światowej, prowadzącej do rodzaju fasadowości unijnych struktur, skrywających nową architekturę polityczną kontynentu. Należy zauważyć, że wspomniana dezintegracja nie musi być zjawiskiem spektakularnym, gdyż może polegać przykładowo na coraz większym ignorowaniu bądź bagatelizowaniu wspólnych reguł i zasad przez państwa członkowskie lub instytucje ponadnarodowe. W takiej sytuacji podmiotowość polityczna, rozumiana jako zdolność do efektywnego funkcjonowania w systemie międzynarodowym celem realizacji interesów własnych obywateli, do której każdy kraj zdaje się dążyć i aspirować, nakazywałaby rozpocząć próby analiz o charakterze autonomicznym. Chodziłoby zatem o dociekania oparte o dozę wewnątrzsterowności, dające nadzieję na samodzielne projektowanie i realizację polityki w sytuacji potencjalnego rozkładu bądź przemodelowania struktur zjednoczeniowych Europy.

Celem autora nie jest zaproponowanie gotowej recepty na wypadek ewentualnego zaistnienia wyżej wymienionych okoliczności, ponieważ wymagałoby to bardziej pogłębionych badań i studiów oraz zbiorowego wysiłku intelektualnego polskich elit, który wydaje się coraz bardziej potrzebny w aktualnej sytuacji polityczno-gospodarczej kontynentu. Tekst ten ukazuje raczej, jakie konsekwencje może mieć myślenie o członkostwie w unijnej wspólnocie w kategoriach bezalternatywności dla bieżącej polskiej polityki i miejsca państwa w Europie, a także jego aktywności i postawy względem procesów toczących się obecnie w Unii Europejskiej oraz podejmowanych tam decyzji.

Hipoteza tej pracy jest następująca: kryzys zjawiska unijnej instytucjonalizacji może prowadzić do nawrotu dawnych podziałów o charakterze centro-peryferyjnym, obniżających rangę m.in. Polski oraz innych krajów regionu w systemie europejskim. Załamanie się dotychczasowego ładu liberalnego w ujęciu globalnym, którego Rzecz- 
pospolita jest niewątpliwym beneficjentem, może $\mathrm{w}$ istocie skutkować reaktywacją bardziej bezpośrednich form dominacji i podporządkowania w stosunkach międzynarodowych, a także zainicjować przemiany ustrojowe polegające na odchodzeniu od prawideł demokracji liberalnej w Europie Środkowo-Wschodniej. W tym miejscu warto zauważyć, iż choć jest to raczej niekorzystna perspektywa z punktu widzenia takich krajów, jak Polska, aktualnie nasze władze, podobnie jak rządy innych państw tego regionu, wydają się nie posiadać ani instrumentów, ani wizji przeciwdziałania temu negatywnemu scenariuszowi, którego nie można wykluczyć.

Metodą zastosowaną w tym tekście będzie analiza jakościowa wybranych treści dotykających problematyki (de)instytucjonalizacji międzynarodowej, szczególnie w kontekście fenomenu unijnej supranacjonalizacji, jak również prac poświęconych paradygmatowi centro-peryferyjnemu.

\section{Rozważania wokól kierunków procesu supranarodowej instytucjonalizacji}

Od lat projekt europejski wydaje się być systematycznie podkopywany przez różne kryzysy, które mogą okazać się potencjalnie destruktywne dla fundamentów całej wspólnoty. Nie tylko w Polsce, ale również w innych krajach członkowskich, brakuje obecnie refleksji na temat konsekwencji jej ewentualnej dekompozycji, a także możliwych scenariuszy dalszego postępowania na wypadek stopniowego uwiądu struktur ponadnarodowych (Ikenberry, 2018, s. 7). Być może powyższe wynika z obawy, iż publiczna debata $\mathrm{w}$ tej sprawie wzmocniłaby tendencje odśrodkowe unijnej wspólnoty, działając niczym samospełniająca się przepowiednia. Zdaniem badaczy konstruktywizmu należałoby raczej unikać takich rozważań, gdyż nadmiar dyskusji i refleksji w tej kwestii mógłby prowadzić do urzeczywistnienia scenariusza dekompozycji UE na szerszą skalę (vide casus Wielkiej Brytanii). A zatem być może nie warto kontynuować przedmiotowych dociekań, gdyż pomimo wspominanych objawów dekoniunktury, większość procesów politycznych i gospodarczych w Unii wciąż funkcjonuje zadowalająco, a niektóre obszary współpracy są obiektem systematycznego pogłębienia i dalszej instytucjonalizacji. Analiza wspomnianej secesji Zjednoczonego Królestwa ze wspólnoty dostarcza bowiem argumentów, że w zasadzie niemożliwe jest wystąpienie ze struktur rynku wewnętrznego i unii celnej, bez narażenia własnego państwa oraz unijnych partnerów na istotne straty finansowe oraz trudności gospodarcze (Niedźwiecki, 2019, s. 9-20). Projektowanie określonej alternatywy dla udziału w unijnych gremiach nie wydaje się mieć pierwszorzędnego znaczenia, ponieważ dostępne dane wskazują na korzyści netto, jakie wciąż przypadają w udziale wszystkim państwom członkowskim.

Jednak mimo powyższego, objawy dekompozycji liberalnego porządku w Europie przejawiają się $\mathrm{w}$ dostrzegalnej kontestacji procesów europeizacyjnych. Coraz bardziej ewidentne stają się symptomy zahamowania, a nawet regresu tych sfer polityki i gospodarki, które dotychczas nasycone były różnorodnymi regulacjami supranarodowymi. Zauważalny staje się rodzaj inercji wywołany tendencjami erozyjnymi, obserwowanymi w ramach gremiów ponadnarodowych. W konsekwencji zanika wiara w prawo jako podstawowy regulator stosunków między państwami i obywatelami, 
a elity stopniowo przestają cieszyć się poparciem społecznym, ponieważ ich postulaty nie stanowią już gwarancji dobrobytu i szans życiowych. Jedną z pierwszych ofiar kryzysu staje się koncepcja budowy wysoce zintegrowanego, supranarodowego polity, mającego w założeniu być emanacją liberalnego porządku społeczno-gospodarczego i politycznego. Tym samym następuje zwrot ku narodowym kontekstom i rozwiązaniom mającym na celu uniknięcie bądź neutralizację zagrożeń, na które zjawisko instytucjonalizacji międzynarodowej przestało być należytą i efektywną odpowiedzią.

Aktualnie istotnego znaczenia nabierają motywacje związane z potrzebą zapewnienia szeroko pojętego bezpieczeństwa, a tymczasem niektóre aspekty kooperacji międzynarodowej zaczynają być postrzegane jako zarzewie sporów i konfliktów. Wcześniej projekt paneuropejskiej współpracy posiadał aprobatę społeczeństw, które upatrywały w nim szans na wzrost dobrobytu i długofalowej stabilności. Obecnie te same społeczeństwa zdają się opowiadać za szerokim wykorzystywaniem narodowych instrumentów, w miejsce dotychczasowych reżimów ponadnarodowych (Jones, 2018, s. 440). Choć zapewnienie pokoju i rozwoju gospodarczego przyświecało założycielom wspólnoty europejskiej po II wojnie światowej, dziś przeważa argumentacja technokratyczna, która w coraz mniejszym stopniu porywa serca i umysły mieszkańców Starego Kontynentu. Unia Europejska traktowana jest wprawdzie jako stały element pejzażu politycznego, jednak jej aktywność wydaje się podsycać frustrację w elektoratach, ponieważ przestaje ona pełnić rolę uniwersalnej recepty na problemy współczesnej Europy.

Dodatkowo ujawieniu ulegają dysonanse i rozbieżności pomiędzy „starymi”, a „nowymi” państwami członkowskimi. Kraje zachodnie prezentują objawy zniecierpliwienia i rozczarowana z powodu imitacyjnej modernizacji państw tzw. „wschodniego rozszerzenia UE", wykazujących niechęć wobec niektórych aspektów procesu integracyjnego, takich jak poszanowanie wspólnych zasad i wartości. W „nowych” krajach członkowskich z kolei pojawia się wątpliwość, czy zachodni członkowie UE rzeczywiście pozwolą na realną i pełną konwergencję „nowej Europy”, która może jawić się jako polityczno-gospodarczy konkurent dla rdzenia organizacji. Z tego względu ujawnieniu ulegają w Europie Środkowo-Wschodniej inicjatywy bardziej autonomicznej i asertywnej polityki względem unijnych struktur, które mogą przybierać formułę odejścia od tzw. wartości europejskich, w tym rządów prawa i trójpodziału władzy. Dodatkowo wciąż zdaje się pokutować w tym regionie postawa tzw. „,newcomers", którzy starają się unikać brania odpowiedzialności za całą strukturę, a zarazem próbują akomodować się do zmieniających się warunków, aby podtrzymać napływ benefitów ze struktur europejskich (Sedelmeier, 2011, s. 17).

Niewątpliwie udział w procesie integracji wymusił spotkanie z „obcymi”, co z kolei zrodziło reakcje obronne pośród dość homogenicznych społeczeństw, gdyż strach przed przybyszami wygenerował potrzebę zahamowania bądź odwrócenia trendów zjednoczeniowych. Unijne instytucje stały się areną głębokich konfliktów politycznych między przedstawicielami ancien régime, a tak zwanymi narodowymi populistami, stawiając pod znakiem zapytania zasadność dalszego funkcjonowania $\mathrm{w}$ otulinie europeizacji, która miała być ostoją rozsądku i umiarkowania dla demokracji narodowych, niezwykle potrzebnego w dobie postępujących zjawisk globalizacyjnych. Skoro proces zjednoczeniowy stracił swą pierwotną efektywność w rozwiązywaniu wspól- 
nych problemów, zdaniem niektórych zakwestionowaniu uległ sens transferu lojalności i kompetencji z poziomu narodowego na płaszczyznę ponadnarodową, szczególnie w dobie perturbacji wywołanych kolejnymi kryzysami.

Dekoniunktura trendów instytucjonalizacyjnych może wynikać z coraz powszechniejszego przeświadczenia, iż bardziej racjonalna od supranacjonalizacji jest renacjonalizacja wybranych obszarów polityki i gospodarki w Europie (Vollaard, 2014, s. 1151). Dotychczas swoboda przepływu towarów, osób, usług i kapitału wiodła do zacieśniania współpracy politycznej, a cyrkulacja ww. czynników produkcji limitowała oddziaływanie rządów narodowych na procesy toczące się w ramach kapitalistycznych gospodarek. Po serii kryzysów dotykających Europę i świat, dość zauważalny stał się rodzaj sceptycyzmu, mogący prowadzić do wniosku, że być może bardziej bezpiecznie jest funkcjonować poza instytucjami ponadnarodowymi, z uwagi na zagrożenia, których te reżimy stały się mimowolnym symbolem. Od tego czasu impuls zjednoczeniowy ewidentnie osłabł, zmniejszyła się liczba starań akcesyjnych do rozmaitych struktur międzynarodowych oraz nasileniu uległy tendencje odśrodkowe w niektórych gremiach polityki światowej. Aktualnie pogłębianie procesu integracyjnego może być interpretowane jako droga do eskalacji kryzysów, toteż elektoraty zaczynają wspierać postulaty delegitymizacji instytucji ponadnarodowych, których efektem jest renegocjacja warunków członkostwa albo przenoszenie ich kompetencji z powrotem na płaszczyznę narodową.

Stosunkowo nowym fenomenem pozostają dążenia dezintegracyjne zainicjowane przez demokracje liberalne, które podejmują ww. aktywność pod wpływem dość wyraźnych oczekiwań społecznych. Opinia publiczna skłania aktorów państwowych do całkowitego lub częściowego wycofywania się z gremiów międzynarodowych, ponieważ znaczące grupy społeczne opowiadają się za podejmowaniem działań jednostronnych w określonych obszarach, kosztem udziału w strukturach multilateralnych. Takie decyzje dezintegracyjne charakteryzują się dość wysokim stopniem demokratycznej autoryzacji, skłaniając państwa do zmniejszenia liczby wspólnotowych polityk publicznych. Instytucje świata zachodniego wprawdzie zakotwiczają demokratyczne formy partycypacji społecznej, jednak wyborcy - mając sposobność oddania głosu - coraz chętniej popierają antyestablishmentowe partie protestu, wspierające tendencje renacjonalizacyjne kosztem spoistości projektu integracyjnego. Paradoksalnie, dojść może do rozsadzenia struktur integracyjnych pod wpływem impulsu wyborczego/referendalnego, wywołanego decyzją społeczeństw krajów członkowskich, oponujących ideom pogłębiania unijnych reżimów, które w założeniu miały zakotwiczać i umacniać instytucje demokratyczne.

\section{Państwo polskie w obliczu dekoniunktury Unii Europejskiej}

W tym miejscu warto przyjrzeć się zagadnieniu polityki Rzeczypospolitej wobec problemu dekoniunktury dotykającej obecnie unijne instytucje. Wciąż znacząca większość polskiego społeczeństwa deklaruje przywiązanie do członkostwa w tejże organizacji, przy czym przeważa motywacja o charakterze ekonomicznym, związana $\mathrm{z}$ pragnieniem pobierania znacznych kwot $\mathrm{z}$ funduszy europejskich. $\mathrm{Z}$ tego 
punktu widzenia perspektywa przejścia Polski w przyszłości na pozycję płatnika netto może na nowo otworzyć dyskusję na temat zasadności jej udziału w unijnych strukturach. Nie bez znaczenia pozostają również kwestie geopolityczne, polegające na woli zachowania bliskich relacji z instytucjami świata zachodniego, które mają gwarantować pokój i bezpieczeństwo w regionie Europy Środowo-Wschodniej. Niewątpliwie, prócz Sojuszu Północnoatlantyckiego, Unia Europejska ma w tym względzie istotną rolę do odegrania, wspierając stabilizację procesów polityczno-gospodarczych na Starym Kontynencie. Jednak przykładowo przywiązanie do tzw. wartości europejskich może już budzić pewne wątpliwości. Idea praworządności i trójpodziału władzy nie wydaje się mieć bowiem pierwszoplanowego znaczenia w ocenach politycznych polskiego społeczeństwa, choć nadal jego istotna część bardziej ufa instytucjom unijnym, aniżeli rodzimym strukturom i tym samym z pewnością bierze pod uwagę głosy dobiegające z Brukseli w zakresie działań polskich władz w rozmaitych obszarach.

Z tego względu polska polityka europejska, niezależnie od partii, która aktualnie sprawuje władzę, wykazuje rodzaj ciągłości w podejściu do członkostwa w Unii, niezmiennie interpretowanego $\mathrm{w}$ kategoriach racji stanu. Powyższe zdaje się nie kolidować ze zmianami w retoryce lub stylu artykulacji preferencji i interesów różnych polskich rządów na forum wspólnoty. Być może generalna nieumiejętność wyobrażenia sobie Rzeczpospolitej poza strukturami europejskimi, nawet $\mathrm{w}$ dobie procesów dekompozycyjnych, wynika z faktu jej głębokiej europeizacji i adaptacji do schematów ponadnarodowych. Wszak nadrzędnym celem kolejnych rządów po 1989 roku było umoszczenie się w europejskiej otulinie, by następnie zająć dogodne miejsce w mającym niebawem powstać supranarodowym polity na kontynencie (Magier, 2012, s. 23). Z pewnością doszło do daleko idącego utożsamienia polskiej racji stanu z interesem ogólnoeuropejskim, co generalnie odpowiadałoby oczekiwaniom naszego społeczeństwa. Obserwowana w ostatnich latach demonstracja atrybutów suwerenności, unikalności własnego doświadczenia historycznego oraz narodowej tożsamości jawi się nie jako votum separatum wobec udziału w procesie integracji, ale jako próba niwelowania poczucia słabości i peryferyjności we wspólnocie. Przybiera to postać swoistej opozycji do koncepcji „funkcjonowania w głównym nurcie UE”, lecz dyskusja wokół tej kwestii wydaje się mieć wymiar raczej wewnątrzkrajowy. W relacjach z unijnymi partnerami i instytucjami, polityka kolejnych polskich rządów zdaje się stanowić kontynuację, niezależnie od ekipy sprawującej władzę w danym momencie. Wspominana ciągłość przybiera formułę m.in. adaptacjonizmu, który rozumiany jest jako podejmowanie działań przede wszystkim na rzecz przystosowania się do polityki wspólnotowych struktur, bez większych ambicji do jej twórczego współkreowania.

Źródeł powyższego zjawiska należałoby upatrywać w meandrach transformacji Europy Środkowo-Wschodniej zainicjowanej na początku lat 90-tych XX wieku, która zdawała się opierać na przeświadczeniu, iż należy odrzucić dotychczasowe nawyki i modele, aby wdrożyć rozwiązania wywodzące się ze struktur zachodnioeuropejskich i móc przystąpić jako w pełni kompatybilny uczestnik do unijnej wspólnoty, postrzeganej jako ostateczny cel działań politycznych (Bauman, 1998, s. 165). Wobec niedostatków własnych, autonomicznych koncepcji rozwojowych, zdecydowano się powielić te schematy, które wiele lat wcześniej przyczyniły się do sukcesu społeczno- 
-gospodarczego krajów Europy Zachodniej. Jednak w rezultacie struktury ustrojowe i ekonomiczne państw tzw. „wschodniego rozszerzenia UE” przeistoczyły się w rodzaj hybrydy, skupiającej w sobie rozmaite rozwiązania napływające ze wspólnoty, które połączono z pozostałościami minionej epoki (Krastev, Holmes, 2018). W tym miejscu można zauważyć, iż kopia nigdy nie będzie odpowiadać oryginałowi, toteż najprawdopodobniej nie istnieje możliwość ostatecznego zniwelowania napięć i rozbieżności między „starymi” a „nowymi” państwami członkowskimi i w ten sposób osiągnięcia pełnej konwergencji w wymiarze społeczno-gospodarczym oraz politycznym. Efektem ubocznym masowej implementacji unijnych norm do krajowego porządku prawnego stało się częściowe transferowanie odpowiedzialności za kierunki rozwoju kraju na poziom Brukseli (Matyja). W związku z tym pojawiło się przeświadczenie, iż strategiczne cele działania Polski oraz innych krajów regionu zostaną zaprogramowane i zoperacjonalizowane na forum całej wspólnoty. Unijne instytucje będą w stanie zaplanować oraz wdrożyć polityki, które przyczynią się do zasypania podziałów między członkami UE. Struktury krajowe miały brać udział w negocjacjach oraz w procesie decyzyjnym toczącym się na unijnym forum, lecz główną rolą, do której były przygotowywane w okresie akcesyjnym, stało się sprawne implementowanie decyzji podjętych przez organizację jako całość. Instytucje wspólnotowe nie tylko miały wspierać wzrost gospodarczy i dobrobyt obywateli poszczególnych krajów członkowskich, ale z czasem - wedle przyjmowanych założeń - miały wręcz zastępować gremia krajowe w definiowaniu polityki ekonomicznej, a nawet zajmować pola związane bezpośrednio z bezpieczeństwem i suwerennością.

Powyższe sprzyjało pokładaniu zaufania w dalsze postępy procesu unijnej instytucjonalizacji, z którym nierozerwalnie połączono losy polskiego państwa i jego obywateli. Unia miała stać się gwarantem nie tylko rozwoju gospodarczego oraz szeroko pojętego bezpieczeństwa kraju, ale także być kotwicą dla tzw. fundamentalnych wartości europejskich, na których został posadowiony model ustroju demokracji liberalnej. Zasady trójpodziału władzy, niezależności sądownictwa czy wiodącej roli praw obywatelskich są głęboko zakorzenione w unijnym systemie integracyjnym, toteż wspólnota przyniosła państwom Europy Środowej i Wschodniej ideę „good governance”, której wdrożenie przyczyniło się do rozwoju społeczno-gospodarczego tego regionu (Thomas, 2013, s. 440). Owo zespolenie z unijnymi strukturami, niezależnie od tego czy rzeczywiste i efektywne czy jedynie symulowane, oprócz ewidentnych korzyści, mogło jednak wieść do rodzaju asymetrycznego uzależnienia, które w przypadku rozpadu bądź marginalizacji unijnej struktury zrodzi potencjalnie daleko idące konsekwencje, szczególnie dla państw tzw. „,wschodniego rozszerzenia UE”. Dekoniunktura unijnych gremiów mogłaby bowiem zainicjować głęboką dekompozycję zdolności tych krajów w obszarze ich polityki gospodarczej oraz szeroko pojętych możliwości instytucjonalnych. Wątpliwe pozostaje, czy państwa te zdołałyby w krótkim czasie odtworzyć struktury państwowe, które zanikły na skutek procesu przekazywania kompetencji na poziom wspólnoty. Jednak rozpad ponadnarodowych struktur, jak się zdaje, nie stanowiłby tylko zagrożenia dla władz centralnych, ale także generowałby wyzwania na gruncie statusu jednostek, które zdecydowały się skorzystać z unijnej mobilności, gdyż doszłoby to obniżenia skali ich ochrony w następstwie osłabienia instytucji unijnego obywatelstwa. Zapewne po wspominanej dezintegracji struktur supranaro- 
dowych właściwe kompetencje musiałyby być na nowo wygenerowane przez władze krajowe, które do tej pory korzystały z ,jazdy na gapę” w okresie pauzy strategicznej wywołanej supremacją paradygmatu liberalnego w stosunkach międzynarodowych. Aktualnie dalsze istnienie sprzyjających warunków geopolitycznych stoi pod znakiem zapytania, a kryzys międzynarodowej instytucjonalizacji uświadamia rudymenty $R e-$ alpolitik.

Mimo dekompozycji liberalnego ładu światowego, państwa Europy Środkowo-Wschodniej zdają się nie posiadać innych opcji, aniżeli schematy, które do tej pory wydawały się najbardziej korzystnym rozwiązaniem dla państw regionu. Powyższe może rodzić daleko idące implikacje m.in. dla bieżącej polityki Polski w Unii Europejskiej. Niedostatek strategicznych alternatyw, w połączeniu ze strachem przed osuwaniem się w kierunku rosyjskiej strefy wpływów, potencjalnie skutkować będzie dużą dozą tolerancji lub wręcz akceptacji dla aktualnych tendencji politycznych we wspólnocie, pomimo ich inercyjnego bądź jawnie niekorzystnego wymiaru dla krajów naszego regionu. W tym sensie zagrożeniem dla nich może być prowadzenie polityki afirmującej członkostwo w strukturach unijnych i bagatelizującej powolny rozkład lub stopniową marginalizację projektu europejskiego, czego niestety nie można wykluczyć. Kryzys integracji europejskiej może być bowiem największym wyzwaniem dla tych krajów, które swój strategiczny rozwój w pełni uzależniły, a zarazem długofalowo powiązały z kierunkami procesu supranarodowej instytucjonalizacji i w związku z tym nie dysponują bardziej autonomicznymi wizjami wzrostu i funkcjonowania, a także narodowymi zasobami organizacyjnymi $\mathrm{w}$ dostatecznym zakresie, aby te założenia zrealizować (Zarycki, 2007, s. 6). Biorąc pod uwagę powyższe, choć fundamenty projektu zjednoczeniowego chwieją się w posadach, wciąż niezwykle mało prawdopodobny jest scenariusz dobrowolnej dezakcesji z unijnych struktur w wykonaniu któregoś z państw Europy Środkowo-Wschodniej, w tym Rzeczypospolitej. Nie wydaje się to obecnie do pomyślenia nawet, jeśli Unia Europejska ulegnie politycznej marginalizacji lub wyrodzi się w projekt niekorzystny z punktu widzenia interesów wspomnianego regionu. Postulaty polexit-u mogłyby zaistnieć w przestrzeni publicznej jedynie w przypadku, gdyby Warszawa przestała być beneficjentem netto budżetu UE, co najprawdopodobniej poszerzyłoby bazę obywateli nastawionych eurosceptycznie i tym samym spowodowało stopnienie proeuropejskich postaw pośród polskiego społeczeństwa.

Już w okresie rokowań akcesyjnych doszło, jak się zdaje, do przyjęcia dość optymistycznego założenia, że wspólnota będzie się pogłębiać, aby przeistoczyć się w rezultacie $\mathrm{w}$ wysoce skondensowane polity, będące stabilnym podmiotem politycznego krajobrazu Europy. Toteż struktury państwowe Polski miały stopniowo „rozpuszczać się" w skupiającym coraz więcej funkcji ponadnarodowym organizmie, przekazując tym samym odpowiedzialność za podejmowanie i realizowanie strategicznych decyzji do gremiów unijnych. To swoiste zrośnięcie się instytucji krajowych ze sferą supranarodową miało służyć transferowi kompetencji z poziomu narodowego na płaszczyznę ponadnarodową, przekształcającą się - jeśli nie w superpaństwo - to w każdym razie w wysoce zintegrowany podmiot regulacyjny, będący w stanie przejąc odpowiedzialność za realizację polityki krajowej. Tak pojmowany proces zjednoczeniowy był w istocie „,perłą w koronie” liberalnego globalizmu, gdzie reżimy ponadnarodowe 
miały tworzyć ramy zabezpieczające wolność jednostki oraz sprawne funkcjonowanie gospodarki rynkowej przed nadmiernym wpływem rządów narodowych (Börzel, Risse, 2003, s. 57).

W dobie kryzysu liberalnych struktur Zachodu powyższy scenariusz staje pod znakiem zapytania, ponieważ gremia te wykazują coraz większe trudności we wspieraniu wzrostu i rozwoju gospodarczego państw członkowskich. Zdaniem niektórych badaczy, są one obarczone wadami systemowymi, które mogą skutkować wręcz generowaniem dekoniunktur ekonomicznych (np. strefa euro). Powyższe nie pozostaje bez znaczenia dla perturbacji wokół projektu integracji europejskiej, których źródłem może być zanik wiary w proces konwergencji i w konsekwencji osłabienie woli implementacji wzorów napływających z centrum do państw Europy Środkowo-Wschodniej (De Santis, Cesaroni, 2016, s. 1516). Powoli przemija też pokusa do odtwórczego naśladownictwa bądź bezrefleksyjnej akomodacji krajów wspomnianego regionu, co wydaje się kolejnym wymiarem kryzysu procesu zjednoczeniowego na kontynencie. W tym miejscu ulega ujawnieniu chęć konsumpcji owoców unijnej współpracy przy jednoczesnym ograniczaniu wkładu własnego i zakresu solidarności z partnerami europejskimi. Prawidłowość ta zdaje się dotykać szczególnie te państwa, które raczej stroniły od prezentacji i promocji własnej koncepcji funkcjonowania Unii jako całości, jej reformy instytucjonalnej bądź postulatów pogłębienia istniejących schematów zjednoczeniowych. Wspomniane kraje raczej nie odegrały większej roli w działaniach mających na celu przeciwdziałanie skutkom takich zdarzeń, jak załamanie gospodarcze w strefie euro, kryzys migracyjny, Brexit, zahamowanie polityki rozszerzeniowej UE czy wzrost zagrożeń geostrategicznych Europy. Polityka europejska tych państw zdawała się polegać wyłącznie na korzystaniu z efektów unijnej kooperacji, bez wykazywania większego zaangażowania $\mathrm{w}$ realną europeizację rodzimych instytucji.

Co warte podkreślenia, UE jako organizacja nie dysponuje narzędziami niezbędnymi do odwrócenia tej tendencji, ponieważ brakuje jej skutecznych instrumentów do pogłębiania adaptacji nowych państw członkowskich, których skala modernizacji zależy w zasadzie wyłącznie od ich wewnętrznych zdolności biurokratycznych, a także woli ich społeczeństw do dokonywania zmian. Zatem w razie osłabienia atrakcyjności modelu prezentowanego przez Zachód, obniżeniu może ulec proces realnej europeizacji struktur środkowoeuropejskich, coraz bardziej rozczarowanych stanem wspólnoty, która przez dziesięciolecia stanowiła cel ich dążen. Zjawisko dekoniunktury integracji europejskiej może oznaczać dalsze pogłębienie tej tendencji, która będzie szczególnie widoczna w krajach Europy Środkowo-Wschodniej, w tym w Rzeczypospolitej.

W sytuacji wysokiej efektywności procesu zjednoczeniowego wpływy ośrodka centralnego mogą promieniować na pozostałe obszary, a jego struktury stają się atrakcyjne dla marginaliów, które chcą naśladować rozwiązania napływające z zewnątrz poprzez system integracyjny. Z tego względu liczne instytucje państw tzw. „wschodniego rozszerzenia UE" zostały skonfigurowane, by lepiej adaptować się do funkcjonowania w sieci gremiów ponadnarodowych, co stanowiło jedno z głównych kryteriów ich akcesji do tej organizacji (Copcea, 2015, s. 165). Przyjęcie przez nie orientacji prozachodniej po 1989 roku przesądziło o działaniach na rzecz recepcji zasad demokracji liberalnej oraz gospodarki rynkowej, mających zakotwiczenie w procedurach europejskich, co było zasadniczym punktem odniesienia dla procesu transformacji syste- 
mowej odbywającej się w tym regionie. W przypadku erozji struktur Zachodu istnieje zatem poważne ryzyko nie tylko przeobrażeń o charakterze geopolitycznym, ale także głębokich zmian ustrojowych i gospodarczych, jako następstwa załamania się procesu konwergencji i harmonizacji Europy Środkowo-Wschodniej. Powyższe może bowiem oznaczać wejście w strefę oddziaływana nowego centrum, które zaoferuje inny model rozwojowy, oparty o odmienne wartości oraz rozwiązania instytucjonalne. W tym sensie wobec braku woli wzięcia odpowiedzialności za określanie strategicznych kierunków polityki w sposób autonomiczny i wewnątrzsterowny, w przypadku dekompozycji unijnych struktur, może pojawić się konieczność adaptacji do nowego porządku, który objawi się w następstwie spadku znaczenia systemu supranarodowej integracji Europy. Jego ramy nie są jeszcze znane i mogą być przedmiotem jedynie spekulacji, lecz sytuacja ta może oznaczać przywrócenie i ugruntowanie bardziej tradycyjnego podziału na centrum i peryferia kontynentu, $\mathrm{z}$ bezpośrednimi formami przemocy i dominacji ze strony aktorów państwowych. W konsekwencji może dojść do wielowektorowego dryfu na marginesie geopolitycznych bloków, upatrujących w krajach wskazanego regionu rodzaju inercyjnego zasobu różnych czynników produkcji.

Ośrodek rdzeniowy bywa zazwyczaj konstruktem niekompatybilnym ze strukturami terytoriów marginesowych, zatem obszary te są skłonne poprzestawać na kopiowaniu schematów pochodzących z zewnątrz, traktując je jako parawan przykrywający amalgamat hybrydowych rozwiązań instytucjonalnych (Krasnodębski, 2003, s. 84). W sferze deklaratywnej jest tam demonstrowana aktywność o charakterze adaptacyjnym, by wykazać dążenie do progresu w dziedzinie transformacji wewnętrznej wedle oczekiwań struktur integracyjnych. $Z$ uwagi na określone komplikacje związane $\mathrm{z}$ tym procesem, marginalia ograniczają się jednak zaledwie do imitowania porządku centrum, umożliwiającego podtrzymanie korzyści napływających ze wspólnoty. Koniunktura epoki „Końca historii” i związana z nią dywidenda pokoju bywa wykorzystywana ledwie do konsumpcji unijnych benefitów oraz powierzchownego naśladownictwa zewnętrznych gremiów, zamiast działań na rzecz bardziej autonomicznego wzrostu, odpowiadającego lokalnej specyfice i potrzebom obszarów marginesowych.

Imitowanie procesu europeizacji, mające na celu szybkie uzyskanie autoryzacji ze strony rdzenia organizacji, miało skracać drogę do dobrobytu na obszarach granicznych. Strategia ta jednak nie przyniosła spodziewanych rezultatów i raczej nie wywołała poczucia satysfakcji i spełnienia. Nieustanne dążenie do wyidealizowanego wzorca wygenerowało w marginalnych obszarach wrażenie niepokoju, zagubienia, a także wyobcowania. Gdzieniegdzie pojawiła się reakcja obronna w postaci ucieczki w swojskość poprzez nawiązanie do osobliwie rozumianej własnej kultury i historii, mająca za zadanie przywrócić poczucie godności i szacunku w świecie asymetrycznych współzależności. Owo zauważalne votum nieufności wobec ingerencji centrum w lokalne sprawy peryferii spotkało się jednak z raczej symboliczną reakcją ze strony rdzenia, który był w stanie ledwie obserwować wspomniane zjawisko, ze względu na dość pozorną możliwość stosowania kar i sankcji. Z tego względu unikanie instytucjonalizacji w ramach wspólnych reguł i standardów, będące niegdyś niepożądaną strategią polityczną, aktualnie bywa coraz powszechniejsze na obszarach peryferyjnych. Perturbacje ekonomiczne podważyły wizerunek Zachodu, który być może nie jest już warty naśladowania, toteż coraz częściej podejmuje się decyzję o zaniechaniu dalsze- 
go umacniania jego instytucji na marginaliach, czemu nie są w stanie przeciwdziałać słabnące gremia ponadnarodowe.

Proces europeizacji oraz członkostwo we wspólnocie wymaga od państwa członkowskiego dość solidnych zasobów gospodarczych i instytucjonalnych, co w przypadku państw tzw. „wschodniego rozszerzenia UE” jest raczej wątpliwie. Jednak funkcjonowanie poza jakimikolwiek strukturami supranarodowymi może wymagać jeszcze większej ilości wspominanych zasobów, które w regionie Europy Środkowo-Wschodniej występują w ograniczonym zakresie. W tym sensie w razie braku implementacji bardziej autonomicznych i motywowanych wewnętrznymi przesłankami projektów strategicznych - jako następstwa dekompozycji struktur europejskich - alternatywą może być konieczność adaptacji do porządku ukształtowanego przez nowy ośrodek decyzyjny (Zarycki, 2000, s. 851). Dla zapewnienia ciągłości funkcjonowania aktualnych struktur wydawać się będzie niezbędnym transponowanie i naśladowanie zasad opracowanych $w$ innych centrach, jeżeli zaniechaniu ulegnie planowanie i poszukiwanie możliwości wdrażania bardziej autonomicznych koncepcji funkcjonowania w stosunkach międzynarodowych.

$\mathrm{Na}$ obszarach peryferyjnych, w których panuje niedostatek rodzimych strategii rozwojowych, raczej nie są brane pod uwagę idee modernizacyjne dopasowane do lokalnej specyfiki, lecz programy dostosowań do schematów transformacyjnych oferowanych przez zewnętrzne struktury (Wallerstein, 1974, s. 129). Jeśli pierwowzór doświadczy dekoniunktury, automatycznie pojawia się tam dylemat, czy wciąż warto go imitować. Replika zawsze bowiem pozostanie namiastką oryginału, który właśnie przeżywa perturbacje, a zatem być może nie warto już za nim podążać. W ten sposób traci popularność zjawisko idealizowania pogrążonego w impasie centrum, które ze swymi trudnościami przestaje reprezentować atrakcyjny model relacji społecznych, politycznych i gospodarczych. Rdzeń ewidentnie nie dysponuje dawną siłą ciążenia, a jego wartości, czyli m.in. otwartość, pluralizm oraz wielokulturowość, w dobie kryzysu postrzegane są jako egzystencjalne zagrożenie dla terenów marginesowych. Wygenerowany przez globalizację strach przed symbolizującymi różnorodność obcymi sprzyja odwrotowi od modernizacji bardziej homogenicznych peryferii (Vachudova, 2014, s. 122).

Naśladownictwo marginaliów oceniane jest przez centrum jako anomalia, raczej niekorzystna dla całego systemu, gdyż ewentualne tendencje dekompozycyjne mogą ulegać pogłębieniu na skutek dysfunkcyjności jego obrzeży. Pod nowoczesną powierzchownością, peryferia zachowują dawne schematy instytucjonalne, a hybrydowe formuły ich organizacji, stanowiące zlepek unijnych norm oraz lokalnej specyfiki, rodzą niezrozumienie w gronie „starych” państw członkowskich. Jeśli marginalia decydują się imitować porządek rdzenia, podejmując zobowiązanie do należytej implementacji rozwiązań normatywnych Zachodu, to centrum wspólnoty automatycznie uzyskuje uprawnienie do ich kontroli, jako reprezentant i prawodawca idealizowanego ustroju społeczno-politycznego i gospodarczego. Stąd udział w procesie unijnej modernizacji może nieść ze sobą poczucie utraty niezależności, a zarazem frustrację wywołaną faktem, iż duplikat nigdy nie będzie odpowiadać pierwowzorowi, przy czym centrum na zawsze pozostanie krytyczne wobec naśladujących je peryferii (Plechanovová, 2011, s. 89). 
Zamierzeniem modernizacji m.in. Polski było osłabienie asymetrii relacji między tzw. „starą” a „nową” Europą. Partycypacja w działaniach integracyjnych miała zapewnić Europie Środkowo-Wschodniej rodzaj otuliny, impregnując ten region przed skutkami długotrwałej peryferyzacji. Udział we wspólnocie miał zapewniać osłonę przed anarchizacją, zakotwiczając tam takie instytucje jak demokracja, gospodarka rynkowa oraz praworząaność. Celem powyższego było umocnienie stabilności, a także bezpieczeństwa tej strefy, aby niwelować wielowiekową dychotomię centro-peryferyjną, generującą spory i konflikty na kontynencie. Pragmatyczne narzędzia transferu wspólnotowych pryncypiów, wspomagane zasadą warunkowości, miały prowadzić do adaptacji niedoskonałej państwowości Rzeczypospolitej oraz jej lepszego zintegrowania z organizmem ponadnarodowym, którego rozwój dokonywał się przez dekady na Zachodzie. Podlegający wspólnotowej socjalizacji liderzy krajów kandydujących do UE uzyskali solidną legitymizację do patronowania wewnętrznym przemianom, ze względu na ówczesną atrakcyjność paradygmatu zjednoczonej Europy. Bagaż instytucjonalny minionej epoki uczynił proces przystosowywania się Europy Środkowo-Wschodniej do unijnych zasad jednak bardziej kosztownym, aniżeli był on dla krajów, które wcześniej przystąpiły do wspólnoty bądź ją współtworzyły (Niedźwiecki, 2014, s. 85).

Przez dziesięciolecia od zakończenia II wojny światowej omawiany region poddawany był sowietyzacji, której zamierzeniem stała się petryfikacja jego peryferyjność w obrębie tzw. „zewnętrznego imperium”, podporządkowanemu moskiewskiemu ośrodkowi decyzyjnemu. W odróżnieniu od powyższego, adaptacja do unijnego porządku miała opierać się nie tylko na implementacji formalnych procedur, lecz również na realnym zinternalizowaniu nowych obyczajów w zakresie metod współzarządzania sprawami publicznymi. Powyżej opisane wyzwania przełożyły się na udział w procesie europeizacji charakteryzujący się jednak dozą braku refleksji oraz konsekwencji. Przejawem tego stało się wdrażanie znacznej ilości aktów normatywnych w zasadzie bez szerszej dyskusji, co mogło prowadzić do powierzchowności modyfikacji wprowadzanych w duchu ,potiomkinowskiej harmonizacji”. Znaczące nakłady ponoszone $\mathrm{w}$ wyniku dostosowań połączono z raczej ograniczonymi zdolnościami biurokratycznymi m.in. Polski, która wcześniej funkcjonowała w środowisku niesprzyjającym przestrzeganiu zasad „dobrego rządzenia” i preferującym supremację polityki nad rządami prawa.

Aktualnie internalizacja wartości europejskich w regionie środkowoeuropejskim, nie wspominając o supranacjonalizowaniu jego lokalnych preferencji na płaszczyznę wspólnotową, wydaje się raczej problematyczna. Ze względu na iluzoryczność ewentualnych sankcji za niepełną implementację unijnego porządku, doszło tam do rozdźwięku między formalnie przyjętymi zasadami a praktyką ich realizacji. W latach 90-tych XX wieku m.in. Rzeczpospolita dążyła do zakotwiczenia własnych struktury w projekcie integracyjnym, jednakże obecnie coraz bardziej ewidentne staje się ograniczanie jej pro-unijnych wysiłków modernizacyjnych. Zjawisko swoistego lewara funkcjonowało prawidłowo przed jej formalnoprawną akcesją do wspólnoty, lecz powstaje wątpliwość czy modyfikacje wówczas zaimplementowane odznaczały się efektywnością, czy też zwiastowały wygenerowanie rodzaju parawanu skrywającego dawne schematy działania. Można skonstatować, że kraje Europy Środkowo-Wschod- 
niej wykazały się w pewnych sferach nienależytą internalizacją norm europejskich, jednak równocześnie Unia okazała się niewystarczająco konsekwentna w egzekwowaniu realizacji przyjętych przez ten region zobowiązań.

Projekt zjednoczenia Europy - za pomocą mechanizmów konwergencyjnych - miał skutkować zasypywaniem historycznych podziałów o charakterze centro-peryferyjnym (Epstein, Jacoby, 2014, s. 88). Pokój, bezpieczeństwo oraz dobrobyt, które wynikały z ponadnarodowej kooperacji, wydatnie przyczyniły się do osłabienia powyższej dychotomii, a integracja europejska stała się narzędziem produkcji międzynarodowych dóbr publicznych, których korzyści są udziałem wszystkich uczestników. Zjawisko europeizacji okazało się jednak mechanizmem dość efemerycznym, którego rezultaty mogą być dyskusyjne na peryferiach. Szeroko pojęty kryzys społeczno-gospodarczy Zachodu sprawił, iż jego model zaczęto postrzegać jako mniej atrakcyjny szczególnie w krajach marginesowych, które dotychczas raczej imitowały transformację wedle standardów europejskich. Dyskusyjne pozostaje zatem, czy rzeczywiście nastąpiła prawdziwa internalizacja unijnych norm w „nowych” państwach członkowskich. Geograficzny podział na centrum i peryferia został zastąpiony rozbiciem obszaru europejskiego na podmioty imitujące i imitowane (Börzel, 2011, s. 6). W określonych sferach marginalia raczej utworzyły maskującą dawne obyczaje fasadę, mogącą stanowić czynnik osłabiający spoistość Unii jako całości. W warunkach wspólnotowych marginalia oponowały procesowi realnej modernizacji, tworząc miraż ich przynależności do wspólnoty, natomiast rdzeń tolerował taki stan rzeczy, zadowalając się powierzchowną metamorfozą obszarów peryferyjnych. Zatem kryzys koncepcji jednolitej struktury organizacyjnej pod względem stosowanych tam prawideł i wyznawanych zasad może skłaniać do podejmowania zróżnicowanych formuł kooperacji, opartych o „zmienną geometrię integracji”, oznaczającą powrót do przednowoczesnych podziałów centro-peryferyjnych na kontynencie.

\section{Zakończenie}

Członkostwo w Unii Europejskiej nadal oceniane jest przez Polaków jako niemające konkurencji, stąd nawet jeżeli proces euro-integracji odznacza się dość zauważalnymi słabościami i niedociągnięciami, a unijna wspólnota nie reprezentuje już tej organizacji, do której Rzeczpospolita wkraczała w 2004 roku, to kolejne ekipy rządowe niezmiennie obstają przy definiowaniu racji stanu w kategoriach udziału państwa w supranarodowych strukturach, mimo ich zauważalnego kryzysu bądź postulatów zmian niewspółgrających $\mathrm{z}$ długofalowymi interesami kraju. W istocie trudno na obecnym etapie wyobrazić sobie alternatywę dla członkostwa Polski w Unii, gdyż państwo to nadal pozostaje i zapewne jeszcze długo będzie pozostawać beneficjentem netto procesów zjednoczeniowych w Europie. Jednak nie wydaje się zbyt roztropnym ignorowanie faktu, iż doszło do ścisłego powiązania losów kraju z organizacją międzynarodową, która doświadcza obecnie dość poważnego i wielowymiarowego kryzysu stawiającego pod znakiem zapytania możliwości jej dalszego funkcjonowania w przyszłości.

Podsumowując efektywność polskiego oddziaływania na kierunki procesu integracji europejskiej, należałoby wskazać na jej dość umiarkowany charakter, który ustę- 
puje miejsca raczej pasywnej akomodacji do zastanej sytuacji, co w razie pogłębiania się dekompozycji unijnych struktur może okazać się strategią zawodną. Warto zatem wykonać ćwiczenie polegające na poszukiwaniu odpowiedzi na pytanie, jaką politykę prowadzić w razie zakończenia „pauzy strategicznej” wywołanej liberalnym momentem w polityce światowej po upadku systemu komunistycznego na początku lat 90-tych XX wieku. Niniejszy artykuł stanowi w istocie zaproszenie do debaty na temat koncepcyjnych i materialnych zdolności do bardziej samotnego ,żeglowania po oceanie polityki światowej”, do czego wiele państw, w tym Polska, obecnie raczej nie jest przygotowanych, a które powoli staje się koniecznością na skutek objawów dekompozycji struktur UE. Wypracowanie nowych kompetencji w tej dziedzinie może okazać się uzasadnione i niezbędne, gdyż instytucje międzynarodowe coraz rzadziej są w stanie wspierać utrzymanie pokoju, bezpieczeństwa oraz dobrobytu, a coraz częściej kojarzą się z ryzykami lub wręcz szeroko pojętymi stratami i problemami. W dobie ich ewidentnej dekoniunktury obywatele coraz przychylniej spoglądają na działania struktur charakteryzujących się stricte narodową legitymizacją, upatrując w tych gremiach istnienia realnych zdolności do przyjęcia odpowiedzialność za los danej wspólnoty w sytuacjach kryzysowych i tym samym dystansując się od haseł typu „więcej Europy", postulujących szeroki przekaz kompetencji na płaszczyznę ponadnarodową, celem wspólnej odpowiedzi na wyzwania międzynarodowe.

\section{Bibliografia}

Bauman Z. (1998), Prawodawcy i tlumacze, Warszawa.

Börzel T. A., Risse T. (2003), Conceptualizing the Domestic Impact of Europe, w: The Politics of Europeanization, red. K. Featherstone, C. M. Radaelli, Oxford University Press.

Börzel T. A. (2011), When Europeanization Hits Limited Statehood. The Western Balkans as a Test Case for the Transformative Power of Europe, KFG Working Paper Series, no. 30, September.

Copcea B. (2015), Integration And Inequalities In The Eastern European Countries, „Annals of 'Constantin Brancusi' University Of Targu-Jiu. Economy Series', (4).

De Santis R., Cesaroni T. (2016), Current Account „Core-Periphery Dualism” in the EMU, „World Economy", 39 (10).

Epstein R. A., Jacoby W. (2014), Eastern Enlargement Ten Years On: Transcending East - West Divide?, „Journal of Common Market Studies”, 52(1).

Ikenberry J. (2018), The End of Liberal International Order?, „International Affairs”, 94/1.

Jones E. (2018), Towards a Theory of Disintegration, „Journal of European Public Policy”, 25/3.

Krastev I., Holmes S. (2018), Explaining Eastern Europe: Imitation and Its Discontents, ,Journal of Democracy", July, https://www.journalofdemocracy.org/articles/explaining-eastern-europeimitation-and-its-discontents-2/, 29.05.2020.

Krasnodębski Z. (2003), Demokracja peryferii, Gdańsk.

Magier M. (2012), Tożsamość peryferyjna. Tożsamość centrystyczna. Lokalne i globalne klopoty z tożsamościa, „Przegląd Politologiczny”, nr 1.

Matyja R., Peryferyjność - wyzwanie czy fatum?, „Ośrodek Myśli Politycznej”, www.omp.org.pl/ artykul.php?artykul=330, 29.05.2020.

Niedźwiecki A. (2019), Brexit a liberalna teoria stosunków międzynarodowych, „Przegląd Europejski”, (1). 
Niedźwiecki A. (2014), Exploring the European Constitutional Sphere. Centre - Periphery perspective, w: Europe in the time of crisis, red. S. Konopacki, Łódź-Kraków.

Plechanovová B. (2011), The EU Council enlarged: North-South-East or core-periphery?, „European Union Politics", 12 (1).

Sedelmeier U. (2011), Europeanisation in new member and candidate states, „Living Reviews in European Governance", vol. 6, no. 1.

Thomas B. C. (2013), Core-Periphery Relations in the European Union and the Role of Central Places in Europe with a Focus on Regional Policy in Britain and Germany, „European Review", 21 (3).

Vachudova M. A. (2014), EU Leverage and National Interests in the Balkans: The Puzzles of Enlargement Ten Years On, „Journal of Common Market Studies”, 52(1).

Vollaard H. (2014), Explaining European Disintegration, „JCMS: Journal of Common Market Studies", $52 / 5$.

Wallerstein I. (1974), The Modern World System: Capitalist Agriculture and the Origins of the European World Economy in the Sixteenth Century, New York.

Zarycki T. (2007), Interdyscyplinarny model stosunków centro-peryferyjnych. Propozycje teoretyczne, „Studia Regionalne i Lokalne”, nr 1 (27).

Zarycki T. (2000), Politics in the periphery: the interpretation of political cleavages in Poland in their historical and international context, „Europe-Asia Studies”, vol. 52, no. 5.

\section{Streszczenie}

Celem tego tekstu jest postawienie pytania o polską politykę w sytuacji ewentualnego pogłębiania się tendencji (dez)integracyjnych w łonie projektu europejskiego. Praca ta stanowi $\mathrm{w}$ istocie zaproszenie do debaty na temat procesu definiowania celów strategicznych naszego państwa, która może stać się nieunikniona w razie zaistnienia zjawisk dekompozycyjnych w strukturach UE, do czego wiele krajów - w tym Rzeczpospolita - aktualnie nie jest przygotowanych. Wypracowanie nowych projektów i modeli w tej dziedzinie może okazać się uzasadnione i niezbędne, gdyż instytucje międzynarodowe coraz rzadziej są w stanie wspierać utrzymywanie pokoju, bezpieczeństwa oraz dobrobytu, a coraz częściej kojarzą się z ryzykami lub szeroko pojętymi stratami. W dobie potencjalnej dekoniunktury struktur supranarodowych, bardziej przychylnie spogląda się na działanie gremiów opartych o narodową legitymację, postrzegając te organizmy jako realne byty, które są zdolne do przyjęcia odpowiedzialności za los danej wspólnoty w sytuacjach kryzysowych, co może oznaczać dystansowanie się od postulatów transferu kompetencji na poziom ponadnarodowy, celem wspólnotowej odpowiedzi na wyzwania transnarodowe.

Słowa kluczowe: Polska, kryzys, dezintegracja, Unia Europejska

\section{What After the Union? \\ Poland and the (dis)Integration Processes in Europe}

\section{Summary}

The purpose of this text is to pose a question about the Polish politics in a situation of possible deepening of (dis) integration tendencies within the European project. In fact, this work is an invitation to a debate on the process of defining country's strategic goals, which may be- 
come unavoidable in the event of decomposition phenomena in EU structures, for which many countries - including Poland - are currently not prepared. The development of new projects and models in this field may prove justified and necessary, as international institutions are less and less able to support the maintenance of peace, security and prosperity, and are increasingly associated with risks or losses in a broader sense. In the era of potential recession of supranational structures, the actions of bodies based on national legitimacy are more favourably viewed, perceiving these organisms as real entities that are capable of assuming responsibility for the fate of a given community in the crisis situations, which may mean distancing from the postulates of transferring competences to supranational level, for the sake of the Community response to transnational challenges.

Key words: Poland, crisis, disintegration, the European Union 
